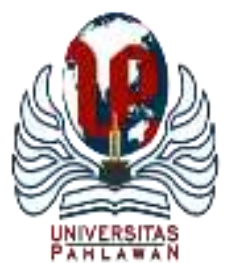

Edukatif : Jurnal Ilmu Pendidikan Volume 3 Nomor 6 Tahun 2021 Halm 4847 - 4857

EDUKATIF: JURNAL ILMU PENDIDIKAN

Research \& Learning in Education

https://edukatif.org/index.php/edukatif/index

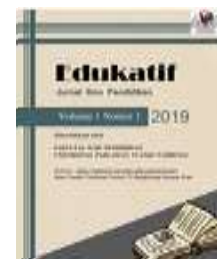

\title{
Persepsi Guru Sekolah Menengah Pertama terhadap Penggunaan Aplikasi WhatsApp dalam Pembelajaran Online Selama Pandemi COVID-19
}

\author{
Muhammad Turmuzi $^{1 凶}$, Laila Hayati ${ }^{2}$, Nurul Hikmah ${ }^{3}$, Eka Kurniawan ${ }^{4}$, Deni Hamdani ${ }^{5}$ \\ Universitas Pendidikan Ganesha, Indonesia ${ }^{1}$ \\ Universitas Mataram, Indonesia ${ }^{2,3,4}$ \\ Universitas Negeri Malang, Indonesia ${ }^{5}$ \\ E-mail : tur.muzi@yahoo.co.id ${ }^{1}$, lailaanugerah@yahoo.com ${ }^{2}, \underline{\text { uyununram @ gmail.com }}^{3}$ \\ ekakurniawan2892@unram.ac.id ${ }^{4}, \underline{\text { deni.math @unram.ac.id }}^{5}$
}

\begin{abstract}
Abstrak
Tujuan penelitian ini adalah untuk mengetahui persepsi guru Sekolah Menengah Pertama terhadap penggunaan aplikasi WhatsApp dalam pembelajaran online selama pandemi COVID-19. Metode yang digunakan dalam penelitian ini adalah metode studi kasus yang menggunakan pendekatan kualitatif. Responden dalam penelitian ini 20 orang guru di SMPN 1 Labuapi Kabupaten Lombok Barat. Pengumpulan data dilakukan melalui teknik triangulasi dengan menggunakan berbagai instrumen, khususnya kuesioner dan wawancara tertulis dengan subjek penelitian. Pertanyaan-pertanyaan dalam kuesioner berfokus untuk menguji pendapat guru tentang penggunaan WhatsApp dalam pembelajaran online. Setelah data terkumpul, peneliti menganalisis data dengan menggunakan teknik analisisi data kualitatif yang dikembangkan oleh Miles dan Huberman. Kesimpulan penelitian ini adalah sebanyak (95\%) responden menyatakan bahwa Grup WhatsApp efektif untuk digunakan dalam pembelajaran online. Semua responden setuju tampilan WhatsApp yang sederhana memudahkan penggunanya saat mengoperasikan aplikasinya.
\end{abstract}

Kata Kunci: Persepsi Guru, WhatsApp, Pembelajaran Online, COVID-19.

\section{Abstract}

The purpose of this study was to determine the perception of junior high school teachers on the use of the WhatsApp application in online learning during the COVID-19 pandemic. The method used in this research is a case study method that uses a qualitative approach. Respondents in this study were 20 teachers at SMPN 1 Labuapi, West Lombok Regency. Data was collected through triangulation techniques using various instruments, especially questionnaires and written interviews with research subjects. The questions in the questionnaire focused on testing teachers' opinions about the use of WhatsApp in online learning. After the data was collected, the researcher analyzed the data using the qualitative data analysis technique developed by Miles and Huberman. The conclusion of this study is that as many as (95\%) respondents stated that WhatsApp Groups were effective for use in online learning. All respondents agree that the simple appearance of WhatsApp makes it easier for users to operate the application.

Keywords: Teacher's Perception, WhatsApp, Online Learning, COVID-19.

Copyright (c) 2021 Muhammad Turmuzi, Laila Hayati, Nurul Hikmah, Eka Kurniawan, Deni Hamdani $\triangle$ Corresponding author:

Email: tur.muzi@yahoo.co.id

DOI : https://doi.org/10.31004/edukatif.v3i6.1571

ISSN 2656-8063 (Media Cetak)

ISSN 2656-8071 (Media Online)

Edukatif : Jurnal Ilmu Pendidikan Vol 3 No 6 Tahun 2021 p-ISSN 2656-8063 e-ISSN 2656-8071 
4848 Persepsi Guru Sekolah Menengah Pertama terhadap Penggunaan Aplikasi WhatsApp dalam Pembelajaran Online Selama Pandemi COVID-19 - Muhammad Turmuzi, Laila Hayati, Nurul Hikmah, Eka Kurniawan, Deni Hamdani

DOI: https://doi.org/10.31004/edukatif.v3i6.1571

\section{PENDAHULUAN}

Seiring dengan perkembangan teknologi pada ponsel pintar (smartphone) yang semakin terjangkau oleh masyarakat, penggunaan berbagai jenis media sosial juga semakin meningkat. (Pustikayasa, 2019, p. 54). Melihat kecenderungan penggunaan media sosial akhir-akhir ini, tenaga pendidik baik itu guru maupun dosen dapat memanfaatkannya sebagai salah satu media pembelajaran untuk mengoptimalisasi proses belajar mengajar, membangkitkan gairah dan motivasi belajar siswa. Selama proses pembelajaran secara online, siswa/mahasiswa menerima materi dan berinteraksi dengan teman sejawat dan juga guru/dosen serta menyelesaikan tugas. Karena memperhitungkan kenyamanan siswa/mahasiswa saat pembelajaran, guru/dosen harus mempunyai kompetensi menciptakan kreasi dan inovasi baru ketika memberikan materi/penugasan.(Eka Susilowati, 2020, p. 3). Menurut Nabilla, et al. (2020, p. 194), pembelajaran online atau virtual learning dianggap sebagai paradigma baru dalam proses pembelajaran karena dapat dilakukan dengan cara yang sangat sederhana tanpa harus bertatap muka di kelas dan hanya mengandalkan aplikasi berbasis koneksi ke Internet sehingga dalam proses pembelajaran tidak memakan waktu dan tempat. Desain pembelajaran juga perlu diperhatikan dalam pembelajaran secara online. Pentingnya desain ini dsebabkan karena dapat menentukan langkah-langkah untuk pelaksanaan pembelajaran dan mengevaluasi hasil belajar. (Turmuzi \& Wahidaturrahmi, 2021, p. 344)

Perkembangan teknologi informasi di era digital berdampak besar pada sistem pembelajaran saat ini, yang tercermin dari pergeseran pembelajaran dari pembelajaran yang berpusat pada guru menjadi pembelajaran yang berpusat pada siswa.(Sofyana \& Rozaq, 2019, p. 81). Penggunaan teknologi informasi, seperti penggunaan internet yang telah memiliki beberapa aplikasi seperti jejaring sosial, merupakan salah satu sarana di mana pengguna dapat saling berkomunikasi, mencari informasi dan menjalin pertemanan. Seperti diketahui, berbagai jejaring sosial tersebut adalah Facebook, Twitter, Line, BBM, WhatsApp, Instagram, Snapchat dan berbagai jejaring sosial lainnya. Salah satu media pembelajaran online yang paling banyak digunakan di masa pandemi COVID-19 ini adalah WhatsApp. Aplikasi ini dipilih karena memiliki beragam fitur keren antara lain perpesanan, obrolan grup, panggilan suara dan video, foto dan video, dokumen, dan pesan suara. Dengan aplikasi WhatsApp, guru dapat dengan mudah mengunggah dan mengirim materi dan tugas melalui pesan. Sekalipun WhatsApp sudah memiliki fitur-fitur canggih yang dapat dimanfaatkan secara optimal dalam proses pembelajaran online, ternyata masih banyak siswa yang belum memanfaatkannya secara optimal baik sebagai media literasi maupun pendidikan. Siswa hanya menggunakan WhatsApp sebagai media sosial untuk mengirim pesan, gambar, atau dokumen yang tidak mengandung literasi atau pendidikan apa pun. Hal ini juga terjadi di Sekolah Menengah Pertama Negeri 1 Labuapi. Dari hasil interview penulis dengan guru saat pelaksanaan kegiatan pengabdian kepada masyarakat dijelaskan bahwa baik siswa maupun guru belum maksimal menggunakan fitur-fitur yang terdapat pada aplikasi WhatsApp.

Krisis kesehatan yang diakibatkan oleh wabah COVID-19 telah mempelopori pembelajaran online secara serempak. (Herliandry et al., 2020, p. 66). Saat ini dunia sedang menghadapi fenomena terkait masalah kesehatan khususnya virus corona atau COVID19, banyak negara yang terkena virus ini, Indonesia salah satunya. Untuk itu, pemerintah mengambil kebijakan penerapan social distancing untuk meminimalisir penularan COVID19. Social distancing yang dimaksudkan adalah menghindari segala macam perkumpulan untuk mencegah penularan COVID-19. Oleh karena itu, semua kegiatan seperti kegiatan Belajar Mengajar (KBM) di sekolah dan universitas sebaiknya dilakukan di rumah atau online untuk menghindari penyebaran COVID19. Dalam pembelajaran online tentunya kita membutuhkan media sebagai sarana pembelajaran. Oleh karena itu, sekolah dan universitas menggunakan platform yang berbeda sebagai sarana pembelajaran tatap 
4849 Persepsi Guru Sekolah Menengah Pertama terhadap Penggunaan Aplikasi WhatsApp dalam Pembelajaran Online Selama Pandemi COVID-19 - Muhammad Turmuzi, Laila Hayati, Nurul Hikmah, Eka Kurniawan, Deni Hamdani

DOI: https://doi.org/10.31004/edukatif.v3i6.1571

muka. Berbagai platform digunakan di universitas maupun di sekolah, termasuk Google Classroom, Zoom Meeting, WhatsApp, Google Meet, dan lain-lain.(Haqien \& Rahman, 2020, pp. 51-52).

Media pembelajaran online yang paling populer dan sering digunakan adalah media pertemuan Google Meet dan WhatsApp. Aplikasi WhatsApp (WA) menjadi salah satu sarana komunikasi yang saat ini disukai oleh seluruh masyarakat. Penggunaan media sosial WA sudah menjadi elemen penting dalam kehidupan sehari-hari untuk berkomunikasi.(Fatkhurrozi et al., 2021). Dari pendapat (Anwar \& Riadi, 2017) mendefinisikan whatsapp sebagai aplikasi chatting yang dapat mengirim dan menerima pesan teks, gambar, video dan lain-lain kepada orang lain dengan menggunakan smartphone jenis apapun yang mendukung komunikasi di seluruh dunia. Dari sisi hasil pembelajaran, pembelajaran online atau jarak jauh sebagai media Grup WhatsApp masih menjadi kontroversi di kalangan pemangku kepentingan dan masyarakat (Darmalaksana et al., 2020). Hal ini dikarenakan pembelajaran online masih dirasa belum lebih baik dari pembelajaran konvensional tatap muka, terutama dalam hal pembelajaran matematika. Paradigma pembelajaran matematika menuntut siswa untuk berpikir kritis agar dapat memahami konsep-konsep matematika yang dipelajari dan mampu menerapkan konsep-konsep tersebut dengan baik dari berbagai respon terhadap masalah matematika. Walaupun banyak fitur canggih yang ditawarkan oleh aplikasi WhatsApp, namun dalam penggunaannya sebagai media pembelajaran online masih menimbulkan permasalahan, hal ini terlihat dari masih adanya pro dan kontra yang terjadi dari kalangan pendidik, siswa dan orang tua murid. Mereka yang tidak setuju dengan penggunaan WhatsApp memberikan alasan karena WhatsApp tidak memiliki filter wajah seperti yang ada di Snapchat, Instagram atau Facebook. Pengguna tidak dapat mengirim file video besar yang lebih dari $16 \mathrm{MB}$ dan dokumen lebih besar dari $100 \mathrm{MB}$ di WhatsApp. WhatsApp memang memiliki stiker tetapi bukan stiker animasi seperti messenger Facebook. Berangkat dari sikap pro dan kontra terhadap penggunaan aplikasi WhatsApp ini maka tujuan penelitian ini adalah untuk mengetahui persepsi para guru yang mengajar di sekolah menengah pertama terhadap penggunaan aplikasi WhatsApp dalam pembelajaran online selama pandemi Covid-19. Dari uraian di atas, maka permasalahan dalam tulisan artikel ini adalah bagaimana persepsi guru Sekolah Menengah Pertama terhadap penggunaan aplikasi WhatsApp dalam pembelajaran online selama pandemi COVID-19.

\section{METODE PENELITIAN}

Metode yang digunakan dalam penelitian ini adalah metode studi kasus yang menggunakan pendekatan kualitatif. Responden dalam penelitian ini adalah 20 orang guru dari SMPN 1 Labuapi Kabupaten Lombok Barat. Dalam tabel 1 ditampilkan data tentang responden.

Tabel 1

Jumlah Data Responden

\begin{tabular}{ccc}
\hline Nomor Responden & Inisial Nama Guru & Jenis Kelamin \\
\hline 1 & SMYONO & Laki-laki \\
\hline 2 & ISWA & Perempuan \\
\hline 3 & SMUDH & Perempuan \\
\hline 4 & NRYNI & Perempuan \\
\hline 5 & NRLA & Perempuan \\
\hline 6 & SFYAH & Perempuan \\
\hline 7 & RKMNI & Perempuan \\
\hline 8 & SDRTI & Perempuan \\
\hline 9 & STSLMH & Perempuan \\
\hline 10 & NSWTNN & Perempuan \\
\hline 11 & LLKFDLAH & Perempuan \\
\hline 12 & HUSM & Laki-laki \\
\hline 13 & DDYISWA & Laki-laki \\
\hline
\end{tabular}


4850 Persepsi Guru Sekolah Menengah Pertama terhadap Penggunaan Aplikasi WhatsApp dalam Pembelajaran Online Selama Pandemi COVID-19 - Muhammad Turmuzi, Laila Hayati, Nurul Hikmah, Eka Kurniawan, Deni Hamdani

DOI: https://doi.org/10.31004/edukatif.v3i6.1571

\begin{tabular}{ccc}
\hline 14 & ERHRYTI & Perempuan \\
\hline 15 & RHMWTI & Perempuan \\
\hline 16 & PINWKAN & Laki-laki \\
\hline 17 & NURHDAH & Perempuan \\
\hline 18 & FITHSANH & Perempuan \\
\hline 19 & NRHIDATI & Perempuan \\
\hline 20 & SPRDI & Laki-laki \\
\hline
\end{tabular}

Pengumpulan data dilakukan melalui teknik triangulasi dengan menggunakan berbagai instrumen, khususnya kuesioner dan wawancara dengan subjek penelitian. Pertanyaan dalam kuesioner diambil dari instrumen penelitian untuk pengembangan aplikasi WhatsApp sebagai alat belajar mandiri yang dikembangkan oleh (Riadil et al., 2020, p. 96). Ada 11 pertanyaan, terdiri dari pertanyaan tertutup dan terbuka. Pertanyaan-pertanyaan ini fokus untuk menguji pendapat guru tentang penggunaan WhatsApp dalam pembelajaran online. Butir Pernyataan kuesioner yang digunakan ditunjukkan pada Tabel 2.

\section{Tabel 2}

Butir Pertanyaan Kuesioner

\begin{tabular}{cl}
\hline No & \multicolumn{1}{c}{ Butir Pertanyaan } \\
\hline 1. & $\begin{array}{l}\text { Apakah Grup WhatsApp dapat digunakan dan efektif untuk mempermudah e-learning } \\
\text { pada masa pandemi COVID-19? (ya/tidak) Berikan Jawaban Secara Singkat! }\end{array}$ \\
\hline 2. & Apakah WhatsApp dapat digunakan kapan saja dan dimana saja? (ya/tidak) \\
\hline 3. & $\begin{array}{l}\text { Apakah aplikasi digital WhatsApp memudahkan anda dalam mengelola grup whatsApp } \\
\text { untuk media pembelajaran online (ya/tidak) Berikan Jawaban Secara Singkat! }\end{array}$ \\
\hline 4. & $\begin{array}{l}\text { Whatsapp memiliki Fitur yang lengkap dalam pelaksanaan pembelajaran online } \\
\text { (ya/tidak) Sebutkan fitur WhatsApp yang anda ketahui! }\end{array}$ \\
\hline 5. & $\begin{array}{l}\text { Apakah Sebuah Aplikasi Digital WhatsaApp dapat Memudahkan guru dalam memantau } \\
\text { peserta didik (ya/tidak) Berikan Jawaban Secara Singkat! }\end{array}$ \\
\hline 6. & $\begin{array}{l}\text { Apakah WhatsApp adalah Alternatif yang tepat untuk media pembelajaran online? } \\
\text { (ya/tidak) }\end{array}$ \\
\hline 7. & $\begin{array}{l}\text { Apakah whatsapp adalah Media yang mudah pengolahannya (maintainable)? (ya/tidak) } \\
\text { Berikan Jawaban Secara Singkat! }\end{array}$ \\
\hline 8. & $\begin{array}{l}\text { Tampilan WhatsApp yang sederhana sehingga memudahkan penggunanya saat } \\
\text { mengoperasikan aplikasinya (ya/tidak) }\end{array}$ \\
\hline 9. & $\begin{array}{l}\text { Apakah menurut anda aplikasi berbasis digital WhatsApp mempunyai Kelebihan dan } \\
\text { Kekurangan WhatsApp? (ya/tidak). Sebutkan dan jelaskan secara singkat! Berikan } \\
\text { Jawaban Secara Singkat! }\end{array}$ \\
\hline 10. & $\begin{array}{l}\text { Kemudahan mengupload/mendownload foto dan video, dan juga fitur Voice Notes untuk } \\
\text { menjelaskan materi melalui aplikasi digital WhatsApp (ya/tidak) }\end{array}$ \\
\hline 11. & $\begin{array}{l}\text { Apakah ada kendala pada orang tua/wali murid terhadap pembelajaran daring melalui } \\
\text { aplikasi berbasis digital "WhatsApp"? (ya/tidak) Berikan Jawaban Secara Singkat! }\end{array}$ \\
\hline
\end{tabular}

Wawancara menggunakan wawancara secara tertulis yang mencakup pertanyaan terbuka. Responden diberikan pertanyaan tertulis untuk dijawab secara tertulis berkaitan penggunaan aplikasi WhatsApp dalam pembelajaran online. dengan para peneliti juga menggunakan pertanyaan lanjutan untuk klarifikasi dan untuk menangkap terungkapnya perspektif mereka. Rossman \& Rallis dalam (Riadil et al., 2020). Wawancara ini difokuskan menggunakan satu set pertanyaan dipandu oleh pertanyaan penelitian. Peneliti mengambil hasil wawancara dan tidak mengubah kata-kata, konteks dan penekanan pertanyaan wawancara untuk setiap para guru. Setelah data terkumpul, peneliti menganalisis data dengan menggunakan teknik analisisi data kualitatif yang dikembangkan oleh Miles dan Huberman dalam (Riadil et al., 2020). 
4851 Persepsi Guru Sekolah Menengah Pertama terhadap Penggunaan Aplikasi WhatsApp dalam Pembelajaran Online Selama Pandemi COVID-19 - Muhammad Turmuzi, Laila Hayati, Nurul Hikmah, Eka Kurniawan, Deni Hamdani

DOI: https://doi.org/10.31004/edukatif.v3i6.1571

Tahapan analisis data yaitu sebagai berikut: Tahap pertama adalah reduksi data, yang merangkum data tentang kontak langsung dengan orang, peristiwa dan situasi di situs pencarian. Langkah pertama ini termasuk memilih dan meringkas dokumen yang relevan. Tahap kedua adalah penyajian data yang merupakan model keempat, karena Miles dan Huberman telah mengklasifikasikannya menjadi 9 model pada bagian penyajian data peneliti menggunakan model keempat, matriks peran, yang menggambarkan pendapat, sikap, keterampilan, atau lainnya dari berbagai peran. Langkah terakhir adalah langkah ketiga untuk melengkapi data dengan triangulasi. Dengan menegaskan arti dari setiap data yang diperoleh dengan satu atau lebih metode, peneliti memperoleh informasi yang dapat digunakan untuk mendukung pencapaian tujuan penelitian.

\section{HASIL DAN PEMBAHASAN PENELITIAN}

Pada bagian ini, peneliti secara berturut-turut mengklasifikasikan dan menganalisis hasil dari angket yang dilakukan pada 20 guru tentang penggunaan media digital WhatsApp dalam pembelajaran dan pengajaran. Tabel 3. menunjukkan data yang diperoleh melalui kuesioner.

\section{Tabel 3}

Persepsi Guru Terhadap Penggunaan WhatsApp Dalam Pembelajaran Online Selama Pandemi COVID-19

\begin{tabular}{|c|c|c|}
\hline \multirow{2}{*}{ Pertanyaan Angket } & \multicolumn{2}{|c|}{ Jawaban Guru (\%) } \\
\hline & YA & TIDAK \\
\hline $\begin{array}{l}\text { 1. Apakah Grup WhatsApp dapat digunakan dan efektif untuk } \\
\text { mempermudah e-learning pada masa pandemi COVID-19? }\end{array}$ & $95 \%$ & $5 \%$ \\
\hline Apakah WhatsApp dapat digunakan kapan saja dan dimana saja? & $100 \%$ & $0 \%$ \\
\hline $\begin{array}{l}\text { 3. Apakah aplikasi digital WhatsApp memudahkan anda dalam } \\
\text { mengelola grup whatsApp untuk media pembelajaran online? }\end{array}$ & $90 \%$ & $10 \%$ \\
\hline $\begin{array}{l}\text { 4. Whatsapp memiliki Fitur yang lengkap dalam pelaksanaan } \\
\text { pembelajaran online }\end{array}$ & $95 \%$ & $5 \%$ \\
\hline $\begin{array}{l}\text { 5. Apakah Sebuah Aplikasi Digital WhatsaApp dapat Memudahkan } \\
\text { guru dalam memantau peserta didik? }\end{array}$ & $55 \%$ & $45 \%$ \\
\hline $\begin{array}{l}\text { A. Apakah WhatsApp adalah Alternatif 1ng tepat untuk media } \\
\text { pembelajaran online? }\end{array}$ & $85 \%$ & $15 \%$ \\
\hline Apakah whatsapp adalah Media yang mudah pengolahannya? & $95 \%$ & $5 \%$ \\
\hline $\begin{array}{l}\text { Tampilan WhatsApp yang sederhana sehingga memudahkan } \\
\text { penggunanya saat mengoperasikan aplikasinya }\end{array}$ & $100 \%$ & $0 \%$ \\
\hline $\begin{array}{l}\text { 9. Apakah menurut anda aplikasi berbasis digital WhatsApp } \\
\text { mempunyai Kelebihan dan Kekurangan WhatsApp? }\end{array}$ & $100 \%$ & $0 \%$ \\
\hline $\begin{array}{l}\text { 10. Kemudahan mengupload/mendownload foto dan video, dan juga } \\
\text { fitur Voice Notes untuk menjelaskan materi melalui aplikasi digital } \\
\text { WhatsApp? }\end{array}$ & $95 \%$ & $5 \%$ \\
\hline $\begin{array}{l}\text { 11. Apakah ada kendala pada orang tua/wali murid terhadap } \\
\text { pembelajaran daring melalui aplikasi berbasis digital whatsApp? }\end{array}$ & $90 \%$ & $10 \%$ \\
\hline
\end{tabular}

Pada pertanyaan pertama terkait efektivitas Grup WhatsApp untuk mempermudah e-learning pada masa pandemi COVID-19, sebanyak (95\%) responden menyatakan bahwa Grup WhatsApp efektif untuk digunakan selama pembelajaran daring. Hasil penelitian oleh Bensulong et al. (2021, p. 90), menyebutkan bahwa pembelajaran daring menggunakan whatsapp dan google form merupakan media paling efektif untuk proses pembelajaran. Hal ini juga didukung oleh hasil penelitian Utomo (2018, p. 210) menyimpulkan bahwa penerapan model pembelajaran berbasis masalah dengan pemanfaatan aplikasi Whatsapp berpengaruh atau berdampak positif terhadap hasil belajar siswa. Lebih lanjut disebutkan bahwa siswa lebih mudah berkomunikasi, dan berkoordinasi tanpa harus bertemu secara langsung. Hasil penelitian yang berbeda di 
4852 Persepsi Guru Sekolah Menengah Pertama terhadap Penggunaan Aplikasi WhatsApp dalam Pembelajaran Online Selama Pandemi COVID-19 - Muhammad Turmuzi, Laila Hayati, Nurul Hikmah, Eka Kurniawan, Deni Hamdani

DOI: https://doi.org/10.31004/edukatif.v3i6.1571

temukan oleh Maulida et al. (2021, p. 3340), yang menyebutkan bahwa proses pembelajaran secara daring melalui grup whatsapp pada siswa tergolong "Belum Efektif", karena bermacam-macam hambatan atau kendala yang dialami siswa bervariasi. Untuk mengetahui alasan dari respon tersebut, peneliti mewawancarai beberapa responden dengan cara memberi pertanyaan tertulis dan jawaban singkat dan menemukan bahwa WhatsApp dinilai sangat efektif karena aplikasi ini sangat mudah digunakan dan memiliki berbagai fitur yang dapat memfasilitasi interaksi antara guru dan murid secara online. Berikut adalah kutipan hasil wawancara dengan terkait pertanyaan pertama:

\section{Tabel 4}

Tanggapan Guru Terhadap Pertanyaan Angket Pertama

\begin{tabular}{cl}
\hline $\begin{array}{c}\text { Kode } \\
\text { Responden }\end{array}$ & \multicolumn{1}{c}{ Komentar } \\
\hline $\begin{array}{c}\text { Responden } \\
1\end{array}$ & $\begin{array}{l}\text { Saya sebagai guru senang dengan adanya aplikasi WhatsApp karena bisa } \\
\text { memudahkan dalam mengajar secara online, dan juga penggunaan WhatsApp } \\
\text { sangat sederhana jadi tidak membuat bingung kita sebagai guru. }\end{array}$ \\
\hline & $\begin{array}{l}\text { Salah satu platform yang sangat mendukung untuk dijadikan suatu tempat } \\
\text { berdiskusi adalah aplikasi WhatsApp, aplikasi tersebut memberikan beberapa fitur }\end{array}$ \\
& $\begin{array}{l}\text { yang sangat menolong kami para guru dan siswa untuk berinteraksi, sehingga } \\
\text { dengan fitur tersebut membuat proses belajar mengajar tetap efektif di masa covid- }\end{array}$ \\
Responden & $\begin{array}{l}\text { 19.”. Meskipun WhatsApp dinilai sangat efektif oleh sebagian besar guru, namun } \\
\text { terdapat beberapa guru yang menilai sebaliknya. Penjelasan di balik respon negatif } \\
\text { tersebut adalah permasalahan terkait keterbatasan kuota internet yang dimiliki oleh }\end{array}$ \\
para orang tua murid. Terdapat juga orang tua murid yang belum begitu paham cara \\
penggunaan aplikasi WhatsApp sehingga memunculkan permasalahan dalam \\
mendampingi proses pembelajaran anak-anak mereka.
\end{tabular}

Selanjutnya, terkait fleksibilitas WhatsApp dalam kegunaannya yang dapat dipakai kapan saja dan di mana saja, seluruh responden menunjukkan kesaamaan persepsi. Chatting dengan WhatsApp bisa dilakukan dengan dua cara, yaitu japri (jaringan pribadi) dan grup. Japri hanya menggunakan WhatsApp untuk berkomunikasi antara dua orang saat grup sedang mengirim pesan ke grup atau komunitas. Grup WhatsApp sering digunakan dalam sebuah kelas, terutama dalam materi pembelajaran yang dimaksudkan untuk menjalin komunikasi antar anggota kelas. (Sa`diyah, 2019, p. 160). Seluruh responden (100\%) menyatakan bahwa WhtasApp dapat digunakan kapan saja dan di mana saja. Pada pertanyaan selanjutnya terkait manfaat grup WhatsApp untuk media pembelajaran online, hasil menunjukkan bahwa $90 \%$ responden setuju bahwa grup WhatsApp memudahkan responden dalam pembelajaran daring karena guru dapat menyampaikan materi secara langsung kepada seluruh murid dalam satu waktu. Hal ini juga sejalan dengan pendapat Hutami \& Nugraheni (2020, p. 130), yang menyebutkan bahwa penggunaan WhatsApp Group merupakan pembelajaran yang mudah dan fleksibel menjadikan aplikasi ini dipilih sebagai media penghubung antara guru, anak, dan orangtua, meskipun kondisi berbatas jarak, ruang dan waktu. Selain itu, fitur berbagi pada WhatsApp sudah sangat lengkap sehingga baik guru maupun murid dengan bantuan wali murid dapat dengan mudah memberikan dan mengumpulkan tugas sekolah. Di sisi lain, $10 \%$ responden tidak setuju akan hal ini. Berikut penjelasan dari responden yang setuju 
4853 Persepsi Guru Sekolah Menengah Pertama terhadap Penggunaan Aplikasi WhatsApp dalam Pembelajaran Online Selama Pandemi COVID-19 - Muhammad Turmuzi, Laila Hayati, Nurul Hikmah, Eka Kurniawan, Deni Hamdani

DOI: https://doi.org/10.31004/edukatif.v3i6.1571

Tabel 5

Tanggapan Guru Terhadap Pertanyaan Angket Nomor 2 dan 3

\begin{tabular}{|c|c|}
\hline $\begin{array}{c}\text { Kode } \\
\text { Responden }\end{array}$ & Komentar \\
\hline Responden 4 & $\begin{array}{l}\text { Ya, karena dengan adanya grup WhatsApp, saya sebagai guru bisa } \\
\text { secara langsung memberikan materi ajar seperti file PPT, Video, Foto, } \\
\text { Voice notes, dan sangat membantu dan memudahkan saya dalam } \\
\text { pembelajaran secara daring/online }\end{array}$ \\
\hline Responden 5 & $\begin{array}{l}\text { Ya, sangat memudahkan saya sebagai guru. Karena WhatsApp memiliki } \\
\text { banyak fitur yang dapat menunjang kebutuhan saya untuk pembelajaran } \\
\text { online seperti mengirimkan berkas materi/tugas berupa foto atau tulisan, } \\
\text { menyampaikan materi/tugas lewat suara (voice note) atau video. }\end{array}$ \\
\hline Responden 6 & $\begin{array}{l}\text { Fitur pesan, telepon dan video call juga ada, WhatsApp juga } \\
\text { memberikan fasilitas video call secara grup, dan itu sangat membantu } \\
\text { kami sebagai guru untuk memberikan materi menggunakan video call } \\
\text { grup. Ada fitur voice note, fitur ini bisa digunakan kalau saya tidak } \\
\text { punya kuota banyak, jadi saya bisa rekam suara saya dalam menjelaskan } \\
\text { materi dan dikirimkan ke grup. Juga terdapat fitur pengiriman foto, } \\
\text { video, dan file seperti pdf, ppt, dan word juga }\end{array}$ \\
\hline Responden 7 & $\begin{array}{l}\text { Fitur WhatsApp memudahkan kita bagi guru untuk tetap berinteraksi } \\
\text { dengan murid melalui fitur-fitur voice note, free call dan video call, } \\
\text { karena dengan fitur tersebut para guru dapat secara langsung } \\
\text { memberikan materi dan mengawasi murid lebih efektif dan efisien. } \\
\text { Disamping itu terdapat fitur lain yang diberikan WhatsApp yaitu } \\
\text { mengirim document, mengirim foto, broadcast, dan lain lain }\end{array}$ \\
\hline Responden 8 & $\begin{array}{l}\text { Ya. Karena fitur-fitur yang diberikan WhatsApp dapat mempermudah } \\
\text { saya saat memantau siswa. Fitur pokoknya adalah grup. Dengan } \\
\text { keberadaan grup, saya dapat mengawasi hasil tugas siswa yang } \\
\text { dikirimkan melalui grup dan mengawasi siswa yang kesulitan dalam } \\
\text { menerima materi. }\end{array}$ \\
\hline Responden 9 & $\begin{array}{l}\text { Ya. Karena banyak fitur dari WhatsApp yang mensupport pembejaran } \\
\text { online mulai dari fitur respon, daftar hadir online, sampai download } \\
\text { materi." }\end{array}$ \\
\hline Responden 10 & $\begin{array}{l}\text { Tidak juga, karena lewat pembelajaran online kita belum tahu apakah } \\
\text { peserta didik itu sendiri benar-benar belajar secara sungguh-sungguh, } \\
\text { dan kita tidak tahu apakah wali murid membantu anak-anak mereka } \\
\text { dalam pembelajaran atau tidak, namun dengan WhatsApp mereka dapat } \\
\text { mengirimkan hasil tugas dan PR mereka yang sudah mereka kerjakan } \\
\text { melalui video, foto, dan lain-lainnya. }\end{array}$ \\
\hline
\end{tabular}

Pertanyaan berikutnya berkaitan dengan pendapat guru tentang penggunaan WhatsApp sebagai alternatif media pembelajaran online. Terdapat $85 \%$ responden menyatakan setuju pemanfaatan WhatsApp sebagai alternatif yang tepat dalam pembelajaran daring, sedangkan sisanya $15 \%$ tidak setuju. Tidak adanya proses tatap muka secara langsung menyebabkan kurangnya kejelasan ketika proses pembelajaran berlangsung. Hal ini dapat terjadi mengingat adanya ketidakefektifan dalam hal pengawasan secara langsung. Berikut ini adalah hasil tanggapan responden atas pertanyaan yang diberikan.wawancara dari beberapa responden 
4854 Persepsi Guru Sekolah Menengah Pertama terhadap Penggunaan Aplikasi WhatsApp dalam Pembelajaran Online Selama Pandemi COVID-19 - Muhammad Turmuzi, Laila Hayati, Nurul Hikmah, Eka Kurniawan, Deni Hamdani

DOI: https://doi.org/10.31004/edukatif.v3i6.1571

Tabel 6

Penggunaan WhatsApp Sebagai Alternatif Media Pembelajaran Online

\begin{tabular}{ll}
\hline Kode Responden & \multicolumn{1}{c}{ Komentar } \\
\hline & $\begin{array}{l}\text { Karena aplikasi WhatsApp membantu para guru dalam pengajaran, } \\
\text { terutama dalam keadaan yang tidak memungkinkan ini, tidak mungkin }\end{array}$ \\
& $\begin{array}{l}\text { saat melakukan pembelajaran tatap muka, karena Lombok Barat pun } \\
\text { masuk ke zona merah dan di himbau tidak boleh adanya pertemuan atau }\end{array}$ \\
Responden 11 & $\begin{array}{l}\text { perkumpulan. Demi mencegah penyebaran COVID-19 ini. Maka dari itu, } \\
\text { saya sebagai guru merasa senang dengan adanya aplikasi WhatsApp } \\
\text { karena dapat memudahkan saya mengajar peserta didik secara online, } \\
\text { dan juga penggunaan WhatsApp begitu sederhana sehingga tidak } \\
\text { membuat bingung saya sebagai guru. }\end{array}$ \\
\hline & $\begin{array}{l}\text { Kita tahu bahwa kita sedang dilanda pandemi virus COVID-19, yang } \\
\text { tidak dapat dipungkiri penyebarannya sangat amat luas, hal ini menuntut }\end{array}$ \\
& pemerintah membuat berbagai rencana bidang pendidikan, upaya yang \\
& dilakukan pemerintah adalah meminimalisirkan pertemuan tatap muka \\
antara individu agar mendukung terputusnya penyebaran virus COVID- & \\
& 19.
\end{tabular}

WhatsApp mempunyai banyak kelebihan dan mungkin juga kekurangan dalam memfasilitasi pembelajaran online. Semua responden $100 \%$ setuju bahwa ada kekurangan dan kelebihan yang ditawarkan aplikasi pesan singkat ini. Tanggapan dari para responden menggambarkan bahwa setiap aplikasi memiliki kelebihan dan kekurangan masing-masing. Oleh karena itu seharusnya guru lebih kreatif dalam proses pembelajaran dengan memanfaatkan setiap fitur yang ada dalam aplikasi tersebut. Menurut Pustikayasa (2019, p. 60) kelebihan Aplikasi WhatsApp adalah pengguna dapat bertukar kontak, membagikan lokasi (share live location), email riwayat percakapan, atur wallpaper dan nada pemberitahuan khusus, juga kirim pesan ke beberapa kontak sekaligus (broadcast). Selain itu peserta didik dengan mudah bisa mengirim balik hasil pekerjaan, baik berupa komentar langsung (chat group), gambar, video atau soft files lainnya yang berhubungan dengan pembelajaran. Sedangkan kekurangan aplikasi WhataApp menurut (Bhagaskara et al., 2021, p. 21), adalah kebanyakan berisi tentang masalah terhadap waktu, yaitu tentang adanya beberapa siswa yang tidak bisa secara tepat waktu mengikuti pembelajaran, baik ketika melaksanakan pembukaan atau ketika pengumpulan tugas. Selain itu aplikasi whatsapp ini memiliki keterbatasan dalam melakukan video call, sehingga tidak bisa mengakomodasi tatap muka secara real time melalui fitur video call bagi semua siswa. (Sa'diyah \& Alfian, p. 6). Berikut beberapa tanggapan responden terkait kelebihan dan kekurangan aplikasi WhatsApp.

\section{Tabel 7}

Kelebihan dan Kekurangan Penggunaan Aplikasi WhatsApp Kode Responden Tanggapan Responden

Kelebihan WhatsApp yaitu memiliki fitur yang cukup lengkap, dan Responden 5 sederhana dalam penggunaannya. Kekurangannya yaitu video call grup sangat dibatasi, hanya dapat digunakan oleh beberapa orang saja. Ya, setiap aplikasi memiliki kelebihan dan kekurangan. Begitu juga dengan aplikasi. Berikut Kelebihan yang dimiliki oleh aplikasi WhatsApp:

Responden 8

1. Sederhana dan fleksibel, aplikasi WhatsApp dapat digunakan di smartphone dan laptop/computer. Sehingga dalam memberikan informasi terkait materi untuk siswa dapat dimana saja dan kapanpun.

2. Kaya dengan fitur yang mensupport pembelajaran secara online seperti grup untuk mengawasi dan mengatur siswa. Fitur 
4855 Persepsi Guru Sekolah Menengah Pertama terhadap Penggunaan Aplikasi WhatsApp dalam Pembelajaran Online Selama Pandemi COVID-19 - Muhammad Turmuzi, Laila Hayati, Nurul Hikmah, Eka Kurniawan, Deni Hamdani

DOI: https://doi.org/10.31004/edukatif.v3i6.1571

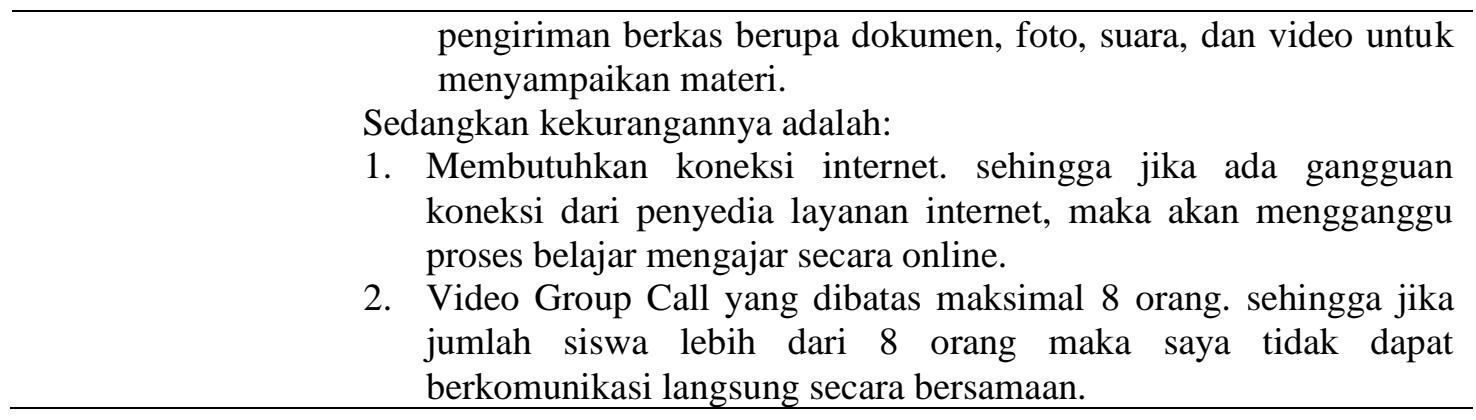

Pada pembelajaran daring, peranan orang tua atau wali murid sangat penting dalam mendampingi proses belajar anak-anak mereka. Tetapi dalam prosesnya pendampingan ini semudah yang dibayangkan. Sebanyak $90 \%$ responden menyatakan bahwa orang tua menemukan kendala dalam pembelajaran online melalui aplikasi berbasis WhatsApp, dan hanya $10 \%$ responden yang menganggap penggunaan WhatsApp tidak menimbulkan kendala berarti bagi mereka. Beberapa responden mengeluhkan sinyal yang tidak stabil yang memberikan dampak bagi proses pembelajaran anak-anak mereka. Terlebih lagi terdapat beberapa di antara mereka masih kesulitan untuk memenuhi kebutuhan kuota untuk akses internet mengingat dampak pandemi COVID-19 menyentuh sektor perekonomian. Menurut Turmuzi et al. (2021, p. 906), faktor kesulitan belajar secara online adalah kesulitan belajar yang berasal dari luar seperti kendala jaringan, kuota, lingkungan tempat tinggal dan juga interaksi antar sesama ketika pembelajaran secara online sedang berlangsung. Berikut hasil tanggapan beberapa responden terkait akan hal ini. Faktor ekonomi juga menjadi kendala orang tua murid dalam pembelajaran berbasis WhatsApp, seperti yang diungkapkan oleh hasil penelitian Sinerjaya \& Fitra ( 2021, p. 31), yang menyebutkan bahwa kondisi ekonomi orang tua yang kurang mampu dalam menghadapi biaya pembelian kuota internet dalam pembelajaran daring dikarenakan pekerjaan orang tua siswa adalah petani. Disatu sisi peran orang tua sangat dibutuhkan dalam pembelajaran online dengan WhatsApp Group. (Dewi \& Laelasari, 2020, p. 266).

\section{Tabel 8}

Kendala Penggunaan WhatsApp

\begin{tabular}{cl}
\hline Kode Responden & \multicolumn{1}{c}{ Tanggapan Responden } \\
\hline & $\begin{array}{l}\text { Ya, kadang-kadang ada beberapa orang tua murid terkendala koneksi } \\
\text { yang tidak stabil dan pemahaman penggunaan WhatsApp yang kurang, } \\
\text { memungkinkan anak menjadi agak sulit untuk menggunakan }\end{array}$ \\
Responden 4 & $\begin{array}{l}\text { WhatsApp sebagai media pembelajaran. Sebaiknya, para guru perlu } \\
\text { memberikan penjelasan tambahan mengenai penggunaan aplikasi }\end{array}$ \\
& $\begin{array}{l}\text { WhatsApp tersebut, namun hal tersebut tidak menjadi masalah yang } \\
\text { besar. }\end{array}$ \\
\hline & $\begin{array}{l}\text { Tidak, karena orang tua/wali murid sudah menggunakan aplikasi } \\
\text { Responden 9 } 9\end{array}$ \\
& $\begin{array}{l}\text { WhatsApp sebelum terjadinya pandemi COVID-19. Sehingga saat } \\
\text { adanya pembelajaran online ini orang tua/wali murid sudah terbiasa } \\
\text { menggunakan aplikasi WhatsApp dan tidak ada kendala. }\end{array}$ \\
\hline
\end{tabular}

Responden 4 menyebutkan bahwa koneksi internet yang tidak stabil menjadi kendala dalam pembelajaran, hal ini berimplikasi pada sulitnya mengunduh materi yang disampaikan guru. Pendapat ini juga sesuai dengan yang disampaikan oleh Saragih \& Ansi (2020, p. 209) dalam penelitiannya yang menyebutkan bahwa Jaringan yang lemah menyulitkan mengunduh materi yang disampaikan guru, banyaknya pesan masuk menyebabkan kinerja ponsel menjadi lemah. Fakta lain menunjukkan bahwa pengawasan orang tua saat pembelajaran dengan WhatsApp berkurang, hal ini disebutkan oleh hasil penelitian (Rigianti, 2020, p. 301) fakta dilapangan menunjukkan bahwa pada minggu awal kegiatan pembelajaran online, orangtua memberikan perhatian penuh terhadap anaknya. Namun pada minggu ke dua dan seterusnya, pengawasan dari orang tua 
4856 Persepsi Guru Sekolah Menengah Pertama terhadap Penggunaan Aplikasi WhatsApp dalam Pembelajaran Online Selama Pandemi COVID-19 - Muhammad Turmuzi, Laila Hayati, Nurul Hikmah, Eka Kurniawan, Deni Hamdani

DOI: https://doi.org/10.31004/edukatif.v3i6.1571

mulai berkurang. hal ini terjadi karena pada saat yang sama, orang tua siswa juga harus membagi waktu antara bekerja, mengurus rumah dan mengawasi belajar anak. Sehingga yang terjadi adalah guru mengirimkan tugas dan orang tua mengirimkan hasil pekerjaan anak. Tanpa adanya pengawasan dalam belajarnya.

\section{KESIMPULAN}

Untuk mempermudah pembelajaran online selama masa pandemi COVID-19, sebanyak (95\%) responden menyatakan bahwa Grup WhatsApp efektif untuk digunakan dalam pembelajaran online. Proses belajar mengajar dengan memanfaatkan teknologi informasi dan komunikasi saat ini, terlebih saat pandemi COVID-19, sangat membantu guru dalam menjelaskan materi kepada para peserta didiknya. Pembelajaran dengan cara seperti ini dapat dilakukan di mana saja tanpa terkendala terkait waktu dan ruang. Untuk mengetahui penyebab tanggapan tersebut, peneliti mewawancarai beberapa responden dan menemukan bahwa WhatsApp dinilai sangat efektif karena aplikasi ini sangat mudah digunakan dan memiliki beberapa fitur yang dapat memfasilitasi interaksi online antara guru dan siswa. Berikut kesimpulan wawancara pada pertanyaan pertama: Salah satu platform yang sangat mendukung untuk dijadikan suatu tempat berdiskusi adalah aplikasi WhatsApp, aplikasi tersebut memberikan beberapa fitur yang sangat menolong kami para guru dan siswa untuk berinteraksi, sehingga dengan fitur tersebut membuat proses belajar mengajar tetap efektif di masa covid-19.

\section{DAFTAR PUSTAKA}

Anwar, N., \& Riadi, I. (2017). Analisis Investigasi Forensik WhatsApp Messanger Smartphone Terhadap WhatsApp Berbasis Web. Jurnal Ilmiah Teknik Elektro Komputer Dan Informatika, 3(1), 1. https://doi.org/10.26555/jiteki.v3i1.6643

Bensulong, A., Afifah, F. N., \& Solikhah, I. Z. (2021). Penggunaan Whatsapp dan Google form Dalam Pembelajaran Bahasa Indonesia di SMK N 2 Sewon Bantul. Lingua Rima: Jurnal Pendidikan Bahasa Dan Sastra Indonesia, 10(1), 85-90.

Bhagaskara, A. E., Afifah, E. N., \& Putra, E. M. (2021). Pembelajaran Dalam Jaringan ( Daring ) Berbasis WhatSapp di SD Yapita. ZAHRA: Research And Tought Elmentary School Of Islam Journal, 2(1), 13 23.

Darmalaksana, W., Hambali, R. Y. A., Masrur, A., \& Muhlas. (2020). Analisis Pembelajaran Online Masa WFH Pandemic Covid-19 sebagai Tantangan Pemimpin Digital Abad 21. Karya Tulis Ilmiah (KTI) Masa Work From Home (WFH) Covid-19 UIN Sunan Gunung Djati Bandung Tahun 2020, 1(1), 1-12.

Dewi, N. P., \& Laelasari, I. (2020). Penerapan Pembelajaran IPA Daring Berbasis Whatsapp Group Untuk Siswa Madrasah Ibtidaiyyah di Tengah Pandemi Covid-19. JURNAL PENELITIAN, 14(2), 249-268.

Eka Susilowati. (2020). Bagaimana Pembelajaran Daring di Tengah Wabah Covid 19 melalui Grup WhatsApp? Jurnal Pendidikan Matematika Raflesia, Vol. 05 No(03), 1-25.

Fatkhurrozi, A., Amaniyah, I., \& Rahmawati, I. (2021). Efektivitas Pembelajaran Daring Menggunakan Google Meet dan Whatsapp Group Untuk Meningkatkan Hasil Belajar Matematika Selama Pandemi Covid 19. MODELING: Jurnal Program Studi PGMI, 28-42.

Haqien, D., \& Rahman, A. A. (2020). Pemanfaatan Zoom Meeting untuk Proses Pembelajaran pada Masa Pandemi Covid-19. SAP (Susunan Artikel Pendidikan), 5(1). https://doi.org/10.30998/sap.v5i1.6511

Herliandry, L. D., Nurhasanah, N., Suban, M. E., \& Kuswanto, H. (2020). Pembelajaran Pada Masa Pandemi Covid-19. JTP - Jurnal Teknologi Pendidikan, 22(1), 65-70. https://doi.org/10.21009/jtp.v22i1.15286

Hutami, M. S., \& Nugraheni, A. S. (2020). Metode Pembelajaran Melalui Whatsapp Group Sebagai Antisipasi Penyebaran Covid-19 pada PAUD di TK ABA Kleco Kotagede. Paudia: Jurnal Penelitian Dalam Bidang Pendidikan Anak Usia Dini, 9(1), 126-130. 
4857 Persepsi Guru Sekolah Menengah Pertama terhadap Penggunaan Aplikasi WhatsApp dalam Pembelajaran Online Selama Pandemi COVID-19 - Muhammad Turmuzi, Laila Hayati, Nurul Hikmah, Eka Kurniawan, Deni Hamdani

DOI: https://doi.org/10.31004/edukatif.v3i6.1571

Maulida, D., Ibrahim, M., Thamrin, M., \& Akhwani. (2021). Implementasi Pembelajaran Daring Melalui Grup Whatsapp pada Siswa Sekolah Dasar. Jurnal Basicedu, 5(5), 3334-3341. https://doi.org/10.31004/basicedu.v5i5.1347

Nabilla, R., \& Kartika, T. (2020). WhatsApp Grup Sebagai Media Komunikasi Kuliah Online. Jurnal Interaksi : Jurnal Ilmu Komunikasi, 4(2), 193-202. https://doi.org/10.30596/interaksi.v4i2.4595

Pustikayasa, I. M. (2019). Grup WhatsApp Sebagai Media Pembelajaran. Widya Genitri: Jurnal Ilmiah Pendidikan, Agama Dan Kebudayaan Hindu, 10(2), 53-62. https://doi.org/10.36417/widyagenitri.v10i2.281

Riadil, I. G., Nuraeni, M., Prakoso, Y. M., \& Yosintha, R. (2020). Persepsi Guru Paud Terhadap Sistem Pembelajaran Daring Melalui Whatsapp Di Masa Pandemi Covid-19. PAUDIA : Jurnal Penelitian Dalam Bidang Pendidikan Anak Usia Dini, 9(2), 89-110. https://doi.org/10.26877/paudia.v9i2.6574

Rigianti, H. A. (2020). Kendala Pembelajaran Daring Guru Sekolah Dasar di Kabupaten Banjarnegara. Elementary School, 7(2), 297-302.

Sa'diyah, H., \& Alfian, M. I. (n.d.). Whatsapp Small Groups Sebagai Media Pembelajaran Maharah Al-Kalam Di Masa Daring. ARABIA: Jurnal Pendidikan Bahasa Arab, 13(1), 1-22.

Sa`diyah, H. (2019). Upaya Menumbuhkan Self-Confidence Berbicara Bahasa Arab Mahasiswa Melalui Grup Whatsappe. Jurnal Al Mi'yar, 2(2), 149-164. https://doi.org/10.35931/am.v2i2.119

Saragih, E. M., \& Ansi, R. Y. (2020). Efektivitas Penggunaan Whatsapp Group Selama Pandemi Covid-19 Bagi Pelaku Pendidik. Prosiding Seminar Nasional Multidisiplin Ilmu Universitas Asahan, 4(September), 207-212.

Sinerjaya, \& Fitra, A. (2021). Analisis Kesulitan Pembelajaran Daring dengan Whatsap. Jurnal Jurnal MathEducation Nusantara, 4(2), 24-32.

Sofyana, L., \& Rozaq, A. (2019). Pembelajaran Daring Kombinasi Berbasis Whatsapp Pada Kelas Karyawan Prodi Teknik Informatika Universitas Pgri Madiun. JANAPATI: Jurnal Nasional Pendidikan Teknik Informatika, 8, 81-86.

Turmuzi, M., Dasing, A. S. H., Baidowi., \& Junaidi. (2021). Analisis Kesulitan Belajar Mahasiswa Secara Online ( E-Learning ) Selama Masa Pandemi Covid-19. Edukatif: Jurnal Ilmu Pendidikan, 3(3), 900910. https://doi.org/: https://doi.org/10.31004/edukatif.v3i3.482

Turmuzi, M., \& Wahidaturrahmi, W. (2021). Analisis Kompetensi Profesional dan Pedagogik Mahasiswa Pendidikan Matematika Dalam Implementasi Kurikulum 2013. Edukatif: Jurnal Ilmu Pendidikan, 3(2), 341-354. https://doi.org/10.31004/edukatif.v3i2.301

Utomo, S. W. (2018). Pemanfaatan Aplikasi Whatsapp Pada Utilization of Whatsapp Application on Problembased Learning for. Jurnal Teknologi Pendidikan, 06(02), 203-204.

file://C:/Users/ASUS/Downloads/Documents/286891-pemanfaatan-aplikasi-whatsapp-pada-pembe2bc25496.pdf 